\title{
Exploitation of Grice's Effective Conversation General Guidelines in The Antara Dua Darjat Film Dialogue
}

Norhidayu Hasan, Zaitul Azma Zainon Hamzah, Nor Azuwan Yaakob and Fazilah Husin

To Link this Article: http://dx.doi.org/10.6007/IJARBSS/v11-i12/11819

DOI:10.6007/IJARBSS/v11-i12/11819

Received: 09 October 2021, Revised: 11 November 2021, Accepted: 29 November 2021

Published Online: 18 December 2021

In-Text Citation: (Hasan et al., 2021)

To Cite this Article: Hasan, N., Hamzah, Z. A. Z., Yaakob, N. A., \& Husin, F. (2021). Exploitation of Grice's Effective Conversation General Guidelines in The Antara Dua Darjat Film Dialogue. International Journal of Academic Research in Business and Social Sciences, 11(12), 776-793.

Copyright: (C) 2021 The Author(s)

Published by Human Resource Management Academic Research Society (www.hrmars.com)

This article is published under the Creative Commons Attribution (CC BY 4.0) license. Anyone may reproduce, distribute, translate and create derivative works of this article (for both commercial and non0-commercial purposes), subject to full attribution to the original publication and authors. The full terms of this license may be seen

at: http://creativecommons.org/licences/by/4.0/legalcode

Vol. 11, No. 12, 2021, Pg. 776 - 793

Full Terms \& Conditions of access and use can be found at http://hrmars.com/index.php/pages/detail/publication-ethics 


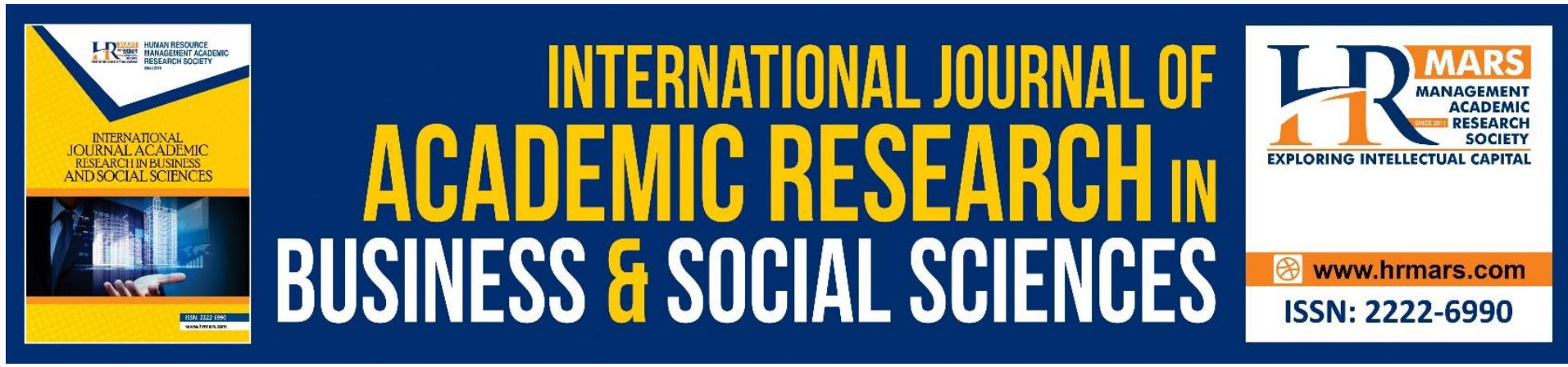

\title{
Exploitation of Grice's Effective Conversation General Guidelines in The Antara Dua Darjat Film Dialogue
}

\author{
Norhidayu Hasan, Zaitul Azma Zainon Hamzah, Nor Azuwan \\ Yaakob and Fazilah Husin \\ Department of Malay Language Faculty of Modern Language and Communication, \\ Universiti Putra Malaysia 43400 UPM Serdang Selangor, Malaysia
}

\begin{abstract}
Exploitation refers to conversational contributions that do not meet Grice's general guidelines of conversation but adhere to the characteristics of effective contributions. This exploitation indicates the use of conversational contributions that do not comply with the CPM but comply with the CP. This CPM guide is sometimes not followed by the participants of the conversation. This study focuses on the exploitation of CPM performed by the Malay community as featured in the film dialogue. Antara Dua Darjat film dialogue is used to descibe how Malay community using conversational contributions that exploit CPM in their daily conversations. The analysis of the study was done using text analysis methods based on Grice's Theory Of Conversation and Relevance Theory. The results of the study found that the exploitation will produce implicatures that are in line with the CP guidelines that is to provide adequate conversational contributions. The use of contributions that exploit CPM also does not lead to misinterpretation of the speaker's true meaning. The exploitation of CPM detected in selected film dialogues can also reflect the way Malay community deliberately do not comply with the general guidelines of the conversation but produce meaningful conclusions and in line with CP guidelines.
\end{abstract}

Keywords: Cooperative Principle Maxims, Exploitation, Malay, Film, Dialogue

\section{Introduction}

Film is known as a media which helps humans view the varieties of cultures and life norms (McQuail, 1994). The screening is where the effort of showing the arts and sharing knowledge happens (Santas, 2001). Film has also become a model for language usage to a community. The real language usage in a community will be expressed through dialogues in film. Dialogues are also sometimes used to represent an identity, a timeline or a setting along with the story line. Besides, Alvarez-Pereyre (2011) stated that dialogues in film could be used as the live conversation model or the real conversation model of a community. Film dialogue could show the different conversation situation based on the sociolinguistic parameter such as age, gender, relationship, social status and others. Film dialogue is also defined as the selected conversation whereas a selected conversation is a speech used to express the right message 
of a story. Bruti (2016) stressed that the different structure of sentences used that dominate the real conversation of a community could be the influence to the film dialogue.

The film audience is classified as the silent listener or the second listener. How important is the right dialogue is when the characters in the film could well picture and understand the dialogue while it could be understood by the audience, too (O'Meara, 2018). In the conversation scope through film, dialogue can be an effective communication if the speech used can be understood by the audience as the second listener and the listener character in a conversation. Thus, Bednarek (2018) explained that whenever dialogue is used, it should show the reality of the real usage of a community language that is represented. Understanding the dialogue can be achieved just like the real conversation when all communication participants manage to understand it.

The process to understand the real meaning of a speaker's speech is not an easy process as it could lead to misunderstanding which could be the cause of ineffective communication. Becoming aware of the misunderstanding, Grice (1975) has proposed a principle which is Cooperative Principle (CP) that divides four main maxims (CPM). The principle and maxims are highlighted by Grice (1975) so that it could be the guide in a communication, hence a successful communication can occur where at the same time contributing to the other conversation participants. Grice explained that communication is a cooperative effort where all speakers have to work together in contributing according to the effective characteristics of the contribution assumptions to avoid the misunderstanding.

\section{Objective of the Study}

This study is based on these two objectives:

1. To discover the exploitation of CPM through a Malay film dialogues.

2. To analyse the speech which exploits the CPM to express effective contribution conversation.

\section{Literature Review}

Kazemi and Ebrahimi (2016) study focuses on the important detail of the application of CP through advertisement and newspapers. This study supports CP implementation as it could produce a successful communication. This study concluded that the writing in advertising and newspapers implemented $\mathrm{CP}$ as well. This study also proved the importance and the effectiveness of $\mathrm{CP}$ since advertisement is one correct medium to convey clear and correct information about the thing that is advertised. CP implementation has successfully helped to convey messages in an easier way.

Andriyani (2015) focuses on the formal conversation aspect of a conversation between a customer service and the customer. This study also found that the customer service staff have implemented CP in every live conversation. This is because it is considered as customer service working ethics (Andriyani, 2015). The working ethics need the employees to convey the correct, truth and in detailed, parallel with the rules of the CP general conversation.

Majeed and Abdulla (2018) on the other hand focused on a formal conversation context between politician and reporter. In a politician's speech context, CP is not implemented in communication in order to maintain and protect certain acts or information. This study found out that politicians will share information implicitly and carefully until the implementation of $\mathrm{CP}$ is ignored in order to care for their self- interest.

Moreover, Zahid (2018) focused on CPM through a television show. The study focused on detecting the CPM and explained the factors of CPM implementation in the related 
conversation. When there is restriction, the CPM is implemented. This restriction somehow occurred because of it is the work ethic and involved the production procedure. Not following the CPM is because speakers should contribute a clear and concise message to the listener.

Furthermore, Simin, Bahadori, and Bagherzade (2016) stated in its study that they used the conversation corpus of the Iran community to see the implementation of CPM. This study found that there is a differentiation between conversation that implements and does not implement CPM between gender. Simin et al (2016) related that women speakers tend to not implement the CPM as they are more polite compared with man speakers. The women speakers prefer to speak politely which makes them not implement the CPM.

Whereas David (2017) stressed in a study about a language in a film by analysing language activity using film conversation of Hitchhiker's Guide to the Galaxy. This study highlighted that film has successfully represented almost real conversation in a community. Film conversation also works as a language model to the people for promoting the real language act in the real community. Besides, the film shows a better real conversation to compare with the language contained in the book.

A study based on the film language use also has been done by Saimon and Hamzah (2019) which has used film as a source of data. The study analysed the speech use understanding used in the film. The results found that the speech use understanding is detected in the film especially in the dialogue that uses metaphor. The metaphor is used by speakers because it has successfully conveyed the correct message and information while representing the personality of speakers. The speech use understanding also could reflect on the language and the culture of the Malay community.

These literature reviews made for the studies related to CP have shown the varieties of type and sources of the studies no matter in the aspect of non-implementing or implementing the CP. According to the discussion made in the previous studies, the results of conversation relating to non-implementing the $\mathrm{CP}$ are when speakers are being rude or making jokes. Whereas the study relating to the exploitation of CPM in Malay community conversation is still barely done. The available studies are only focusing on the speakers using Malay language as a second language and a restricted formal conversation because of some ethics or certain requirements. Meanwhile, studies that used films are mostly analysing the implication of meaning produced without stressing on the implication produced that has the effective contribution characteristic and communication benefits to all participants.

\section{Methodology}

This study uses the conversation data from a Malay film entitled Antara Dua Darjat (1960). The choice of film is based on the reflection of the real Malay community lifestyle with a diversity of the dialogue according to the beauty of the Malay language itself. The film Antara Dua Darjat (1960) is chosen because it is still relevant in the Malay society nowadays. The language use is easy and can be comprehend by all, be it in different races and ages. This film is also showing how the Malay community faces problems or life conflict that involves themes such as family, society and humour. With these themes, the dialogue used in the film of course will have its differences and varieties. These make the film Antara Dua Darjat (1960) is suitable as the data for human communication study. The exploitation of CPM analysis is done to all conversations that are detected in the film. Conversations occurred among the main characters, among the side characters and between the main characters and the side characters have been analysed. 
This study uses qualitative methodology as it is based on analysing the data collected. It started with appointing the conversations that do not implement CPM. The detected conversations are transcribed and divided to the types of CPM which are Maxim of quantity (MQT), Maxim of quality (MQL), Maxim of relation (MRL) and Maxim of manner (MMN). After the data of conversations are divided into types, it is analysed based on the theory in order to explain the exploitation and elaborate the speech meaning that exploits the CP Maxims.

\section{Theoretical Framework}

\section{Grice Conversation Theory}

Grice Conversation Theory (1975) is a theory that provides a general guide to effective communication. The desire or the need for this characteristic of effective contribution naturally exists in human beings. This general guide is also applied unconsciously by communication participants. This theory also emphasizes the general assumption of the contribution that every human being has when they are involved in the communication process. The general assumption of conversation is that every communication process should provide adequate information, not misleading, not contain untrue information or not provide information that is not related to each other. The following is a summary of the requirements according to the maxim in Table 1:

\section{Table 1. Summary of CPM}

\begin{tabular}{|c|c|c|c|}
\hline Maxim & Focus & & Maxim Details \\
\hline \multirow[t]{3}{*}{ MQT } & $\begin{array}{l}\text { Relating to contribution } \\
\text { of quantity }\end{array}$ & a) & $\begin{array}{l}\text { Make each conversation contribution } \\
\text { according to the needs of the purpose } \\
\text { of the conversation }\end{array}$ \\
\hline & & b) & $\begin{array}{l}\text { Make sure the contribution is as } \\
\text { informative as the listener wants }\end{array}$ \\
\hline & & c) & $\begin{array}{l}\text { Not giving contribution more than } \\
\text { what is needed. }\end{array}$ \\
\hline \multirow[t]{2}{*}{ MQL } & Relating to the quality & a) & Not stating anything that is untrue \\
\hline & & b) & $\begin{array}{l}\text { Do not state something that has no } \\
\text { evidence }\end{array}$ \\
\hline MRL & Relating to the relevance & a) & $\begin{array}{l}\text { Make relevant contribution or } \\
\text { relevant to the purpose of the } \\
\text { discussion }\end{array}$ \\
\hline \multirow[t]{3}{*}{$\mathrm{MN}$} & Relating to the manner & $\begin{array}{l}\text { a) } \\
\text { b) }\end{array}$ & $\begin{array}{l}\text { Clear and unambiguous contributions } \\
\text { Avoid uncertainty in contributions }\end{array}$ \\
\hline & & c) & $\begin{array}{l}\text { Make a clear contribution (avoid } \\
\text { unnecessary or exaggerating) }\end{array}$ \\
\hline & & d) & Contributions that is in order \\
\hline
\end{tabular}




\section{Relevance Theory}

Relevance Theory (Sperber \& Wilson, 1986/1995, Wilson \& Sperber, 2002 and Wilson, 2016) is a theory based on relevant definitions and two relevant principles. The two principles are the Cognitive Principle and the Communicative Principle. Cognitive Principles suggest that human cognition will maximize the relevance of speech by itself. Communicative principles suggest that the utterances used will bring up the best assumptions and needs of the listener.

\section{Relevance Concept}

Humans naturally have a desire to obtain information that is relevant to themselves (Sperber \& Wilson, 1995). Humans can also distinguish between relevant information and irrelevant information or even more relevant information and less relevant information to themselves. The relevance of this information can be related to the context because there will be information that is not relevant to one context but will be relevant to another one.

Assumptions will only be relevant in a context if the contextual effect is present in that context. This theory also emphasizes that the relevance of speech can be related to the level of the speech process. If the higher the cognitive effect and the lower the mental process needed to conclude the assumption then the value of the relevance of the utterance will be higher.

\section{Relevance Principle}

Based on the Principles of Cognitive Relevance, human cognitive systems will naturally process information that is assumed to have the highest relevancy value to them and build a context that allows the inference system to maximize the relevance of the input. Meanwhile, based on the Communicative Relevant Principle, to communicate with someone is to attract the listener's attention and provide relevant information to the listener. The speaker should ensure that the utterances used are relevant to the listener in this regard because the listener will pay attention to information that is relevant to him or herself. Sperber and Wilson (1995) state that an utterance will be relevant based on two conditions, namely the ostensive stimulus is relevant enough to make the listener process the utterance and the ostensive stimulus is most relevant to the ability and reference of the listener and speaker. 


\section{Results and Discussion \\ Exploitation Conversation 1}

Table 2. Exploitation Conversation 1

$\begin{array}{ll}\text { (a) Ungku Karim } & \begin{array}{l}\text { Ungku Zaleha, mengapa basah kuyup begini? } \\ \text { Ungku Zaleha, why are you soaking wet? }\end{array} \\ \text { (b) Zaleha } & \begin{array}{l}\text { Tadi kereta kita tersangkut di lumpur ayahanda. Nasib } \\ \text { baik ada pemuda-pemuda kampung. Kalau tidak } \\ \text { sudah tentu kereta kita tak dapat nak bergerak } \\ \text { Our car got stuck in the mud earlier. Luckily there } \\ \text { were village youths. Otherwise our car will not be } \\ \text { able to move. } \\ \text { Oh, jadi anakanda juga turun menolak bersama-sama } \\ \text { ya. } \\ \text { Oh, so you came down and pushed together?. } \\ \text { (c) Ungku Karim ayahanda } \\ \text { Yes father. } \\ \text { EC1/00.21.27 }\end{array} \\ \end{array}$

MQT emphasizes the quantity of information provided by the speaker in a communication. This MQT guide is also closely related to the delivery of necessary contributions according to the amount expected by the listener (Grice, 1975). MQT explains that speakers need to provide information not more than necessary and also not provide less information than necessary. This MQT non-compliance occurs when the speaker provides insufficient information to the listener (Ngenget, 2017).

This MQT non-compliance can be detected in the Exploitation Conversation 1 (EC1) in the 00.21.27 minutes in the utterance $(E C 1 / b)$. Before explaining the utterance $(E C 1 / b)$, the utterance $(E C 1 / a)$ should be explained first. Speech (EC1/a) is an example of speech that complies with CPM but contains implicature. The utterance (EC1/a) should be emphasized because there is a meaning that goes beyond the meaning of the utterance used. Ungku Karim stated "why are you soaking wet", there is another expression "how can you be in the rain?" may be more relevant to the situation as Ungku Karim and Zaleha at that time both knew that the rain was falling heavily. So, question (EC1/a) Ungku Karim wants to know how Zaleha can be hit by rain.

The exploitation of MQT can be detected when Zaleha answered Ungku Karim's question in the statement (EC1/b) "Our car got stuck in the mud earlier. Luckily there were village youths. Otherwise our car will not be able to move.". The conversation between Zaleha and Ungku Karim occurred when Zaleha had just arrived home by car when her body was wet. Based on the context of the situation, Zaleha got in the car brought by her driver. Due to the heavy rain, Zaleha's car tires got stuck in a muddy road. At first Zaleha who was initially in the car and did not get down to push the car with the village youth, but after the attempt to push the car failed, Zaleha decided to get down to help.

Ungku Karim's question was answered using a statement (EC1/b) which is a statement that does not comply with the MQT guidelines by giving excessive contributions from the listener needed. Wilson and Sperber (2006) explain that the characteristics of a speech can be used as input to human cognitive processes to help draw relevant conclusions. Therefore, in order to understand this excessive contribution, the listener can use the information supplied in the utterance as input to be a beginner context. 
Input based on the utterances used by Zaleha can be used as the beginner context is "car condition" and "the village youth help". Zaleha is seen to have provided the relevant beginner context to answer the questions posed by Ungku Karim. The mental process will be involved when Ungku Karim relates the input to the existing context. Relevance theory emphasizes that input will be relevant when it can be linked to background information (Wilson \& Sperber, 2006). Listeners know that the contribution made by Zaleha through "car condition" and "village driver helps" is relevant to her.

Based on the context of the statement, Zaleha has informed that this car can not move can be seen in the statement that came after that "Oh, so you came down and pushed together?". Zaleha has also provided a context of knowledge about her condition which is assisted by the village youth. The same goes for the information "Otherwise our car will not be able to move" which helps expand the context that cars cannot move. The context provided can help Ungku Karim. Apart from that, based on the environmental context, Ungku Karim knew that at that time it rained heavily. Listeners also know that Zaleha will only get wet if Zaleha stands outside and does not sit in the car. Based on the input given by Zaleha and reinforced with the context of the environment and the knowledge of the listener, the premises that can be formed are as follows:

Premises 1) The car stucks in the mud

2) Mud has restricted the movement of the car

3) The speaker did something to remove the car from the mud

4) The speaker was helped by the village youths

Based on the premise formed, the resulting contextual effect is "speaker was in the rain while pushing the car". The resulting contextual effect is relevant because it is successfully linked to the input given by Zaleha and also the context of Ungku Karim's knowledge. The process of analyzing speech $(E C 1 / b)$ is also easy to do because the speaker is seen to provide context to the listener. So the conclusion of the statement $(E C 1 / b)$ can be easily made by the listener. This is evidenced by the statement (EC1/c) "Oh, so you came down and pushed together?". This utterance (EC1/c) proves that the listener can infer the true meaning of utterance $(E C 1 / b)$. The utterance (PE1 / d) also proves the effect of the context constructed by the listener and proved in $(E C 1 / c)$ is highly relevant.

This conclusion is relevant to the listener because it can be linked to the listener's questions even if the speaker uses utterances that provide more information than what the listener needs. Based on the conclusion "speaker was in the rain while pushing the car", said (EC1/b) "Our car got stuck in the mud earlier. Luckily there were village youths. Otherwise our car will not be able to move". This can be explained as exploitation because the speaker has supplied sufficient information at the implied level. Although the utterances used by these speakers provide more information than necessary, yet the resulting contribution can meet the needs of the conversation.

This statement (EC1/b) can be explained as MQT exploitation because Zaleha provides feedback that can be used by Ungku Karim to draw a conclusion. This statement (EC1/b) is also seen to fulfill the concept of cooperation because Zaleha has provided a reference that can help Ungku Karim get the desired answer. Zaleha's cooperation efforts can be explained in the use of information "car condition" and "village youths help". 
This statement $(E C 1 / b)$ is also a rational and relevant contribution to the question (EC1/a) because it has provided sufficient information to the listener by exploiting MQT. Therefore, when she said (EC1/b) "Our car got stuck in the mud earlier. Luckily there were village youths. Otherwise our car will not be able to move" can be explained as MQT exploitation because the speaker has provided information that can help the listener to make a conclusion. This conclusion can then be linked to the concept of cooperation which the information provided is sufficient to answer the listener's questions. This also proves that although the utterance $(\mathrm{EC} 1 / \mathrm{b})$ gives a contribution that does not answer the question according to the required amount, the utterance can be explained as an effective contribution because it successfully answers the question posed. The following is a summary of MQT exploitation discussion.

Table 3. MQT Exploitation Summary

\begin{tabular}{|c|c|c|c|c|}
\hline Utterances & $\begin{array}{l}\text { Exploitation } \\
\text { Strategy }\end{array}$ & $\begin{array}{l}\text { Exploitation } \\
\text { Maxim }\end{array}$ & Implicature & $\begin{array}{l}\text { Purpose of } \\
\text { Exploitation }\end{array}$ \\
\hline $\begin{array}{l}\text { Ourcargot stuck } \\
\text { in the mud } \\
\text { earlier. Luckily } \\
\text { there were } \\
\text { village youths. } \\
\text { Otherwise our } \\
\text { car will not be } \\
\text { able to move }\end{array}$ & $\begin{array}{l}\text { Provide more } \\
\text { information } \\
\text { than needed }\end{array}$ & $\begin{array}{l}\text { MQT- do not } \\
\text { contribute more } \\
\text { than necessary }\end{array}$ & $\begin{array}{l}\text { The speaker } \\
\text { who got wet } \\
\text { when the } \\
\text { speaker went } \\
\text { down to push } \\
\text { the car }\end{array}$ & $\begin{array}{l}\text { Informing } \\
\text { listener }\end{array}$ \\
\hline
\end{tabular}

\section{Exploitation Conversation 2}

Table 4. Exploitation Conversation 2

\begin{tabular}{|c|c|c|}
\hline (a) & Ghazali & $\begin{array}{l}\text { Zaleha, kalaulah ayahanda mu tahu tentang } \\
\text { perhubungan kita. Bagaimana Zaleha? } \\
\text { Zaleha, how if your father found out about our } \\
\text { relationship? }\end{array}$ \\
\hline (b) & Zaleha & $\begin{array}{l}\text { Berkecai urat sarafnya } \\
\text { It would shattered his nerves } \\
\text { EC2/00.52.22 }\end{array}$ \\
\hline
\end{tabular}

$M Q L$, on the other hand, details the guidance in communication related to the content of the contribution, in contrast to MQT which emphasizes the amount of contribution. MQL advises speakers to provide correct information. This maxim also emphasizes that the content of the contribution must be true and each contribution must have proof (Grice, 1975). This MQL non-compliance will occur when the speaker conveys something that is not true.

This MQL exploitation can be detected in Exploitation Conversation 2 (EC2). The utterance $(E C 2 / b)$ is identified as the utterance that exploits MQL. Based on Exploitation Conversation 2 (EC2), this statement (EC2/b) is the answer to the question asked in (EC2/a) "Zaleha, how if your father found out about our relationship?". The conversation took place when Ghazali met with Zaleha in secret and they had hidden their relationship from Zaleha's father. This question (EC2/a) means how Zaleha's father is going to act if he finds out that Zaleha is in a relationship with Ghazali. 
Ghazali's question was answered by Zaleha with (EC2/b) "It would shattered his nerves". This statement $(E C 2 / b)$ is seen to have not met the MQL guidelines by giving untrue contributions and has no evidence. To understand the meaning of the utterances used by Zaleha, the listener can apply the beginner context that has been supplied in the utterances used.

The beginner context for this (EC2/b) is what the listener knows about "It would shattered his nerves". Zaleha has provided the relevant beginner context to help Ghazali understand the true meaning of her words. The listener will pay attention to his knowledge with what is said to be "It would shattered his nerves". Wilson and Sperber (2006) explain that in the speaker's speech the relevance of the utterance can also be achieved through observation to the utterance that can be a reference. Through these observations, the listener will know that the information is relevant to him.

"Shattered" carries the meaning of something broken or shattered into smaller parts. "Nerves" is a nerve that connects the brain with other limbs. With reference to the condition of Zaleha's father, the context of the beginner through this encyclopedic entry gives an assumption "the channel that connects the brain with Zaleha's father's limbs will break into smaller parts". The listener knows this context alone is not enough to conclude what Zaleha meant. Zaleha as a speaker has provided information that can help Ghazali. Ghazali will use this input given by Zaleha and connect with the background context.

Based on the context of the listener's experience, Ghazali knows that Zaleha's father does not like Zaleha associating with low-ranking people. This knowledge of Ghazali is further strengthened by the different level standards between Zaleha and Ghazali. Zaleha is a girl from royal lineage while Ghazali is just a village youth. In addition, the listener can apply the speaker's belief that Zaleha knows and believes that her father will disagree about their relationship.

To analyze the meaning (EC2/b) of "It would shattered his nerves" Ghazali will connect the input with the available background context and form the following premise

Premises Zaleha's father's nerves will burst
2) The duct that connects Zaleha's father's limbs and brain will
break into small parts
3) This happens when found out about the relationship
between Zaleha and Ghazali
4) Zaleha's father's condition would be worse if he found out
about this

Based on the context, the listener can conclude that the meaning of the statement $(E C 2 / b)$ is "Zaleha's father is going to be so angry". The effect of this context is relevant because it can be linked to the context of the belief of the knowledge of the speaker and the listener that Zaleha's father forbade Zaleha to associate with people in lower rank. The inputs that are available through reference to the utterances used are proven relevant because they can be related to the context involved. This coincides with the argument of Wilson and Sperber (2006) that the input for the comprehension of the expression present in the utterance will be relevant if it relates to the background knowledge of the listener to help the listener conclude the effects of the context. Based on the conclusion "Zaleha's father is going to be so angry", this statement (EC2/b) "It would shatter his nerves" can be explained as the 
exploitation of MQL because the speaker has given the correct information at the level implied.

Grice (1975) explains that exploitation is detected in utterances that give untrue contributions at the literal level but contain true contributions according to the level being implied. The statement (EC2/b) "It would shatter his nerves" gives an untrue contribution to the question (EC2/a) however, the speaker is seen exploiting MQL by deliberately providing information that can be a reference to the listener to draw conclusions. The speaker deliberately uses the words "shatter" and "nerves" to encourage the listener to get meaning from the utterances that do not comply with the MQL. Apart from that (EC2/b) "shatter his nerves" can be explained as a statement that exploits MQL because the resulting contribution is to meet the needs of CP. Although literally Zaleha has given a statement that does not comply with $\mathrm{CP}$ and $\mathrm{MQL}$, the conclusion of the resulting contribution can meet the needs of $\mathrm{CP}$ which Zaleha has given a true contribution according to the purpose and needs of the conversation that took place.

Thus, the utterance (EC2/b) "shatter his nerves" can be explained as exploitation because the speaker supplies the correct information through the contribution of untrue conversation to help the listener conclude the true meaning of the utterance. This conclusion is proven to be related to the concept of cooperation that is, the contribution given is true and has evidence. This also proves the utterance (EC2/b), although it does not provide true information to the speaker's question, the utterance is considered a relevant contribution because it can answer the question posed. Here is a summary of the MQL exploitation discussion.

Table 5. Summary of Exploitation MQL

\begin{tabular}{|l|l|l|l|l|}
\hline Utterances & $\begin{array}{l}\text { Exploitation } \\
\text { Strategy }\end{array}$ & $\begin{array}{l}\text { Exploitation } \\
\text { Maxim }\end{array}$ & Implicature & $\begin{array}{l}\text { Purpose of } \\
\text { Exploitation }\end{array}$ \\
\hline $\begin{array}{l}\text { It would } \\
\text { shattered his } \\
\text { nerves }\end{array}$ & $\begin{array}{l}\text { Giving incorrect } \\
\text { feedback. }\end{array}$ & $\begin{array}{l}\text { MQL- Do not } \\
\text { say something } \\
\text { you feel is not } \\
\text { true }\end{array}$ & $\begin{array}{l}\text { Zaleha's father } \\
\text { would be very } \\
\text { angry if he found } \\
\text { out about her } \\
\text { relationship }\end{array}$ & $\begin{array}{l}\text { State information } \\
\text { ind }\end{array}$ \\
\hline
\end{tabular}

\section{Exploitation Conversation 3}

Table 6. Exploitation Conversation 3

\begin{tabular}{ll}
\hline (a) Ungku Mukri & Saya nak ke singapura. Ungku Aziz nak ikut? \\
& I am going to Singapore. Do you want to follow, \\
& Ungku Aziz? \\
& Maafkan saya. Badan saya terlalu letih. \\
(b) Ungku Aziz & Baiklah kalau begitu tolong temankan isteri saya \\
& Alright, then you can help to have a look for my \\
(c) Ungku Mukri & wife. \\
& EC3/01.19.26 \\
\hline
\end{tabular}

MRL is a maxim that details that each conversation contribution should be related to the purpose or direction of the conversation. This MRL emphasizes that the speaker should provide information that is relevant and relevant to the topic of conversation (Grice, 1975). 
This MRL non-compliance occurs when the speaker provides information that is not related to the needs of the listener. When the speaker states something that is directly irrelevant, irrelevant or not in line with the discussion then the speaker is not complying with MRL in his speech (Levinson, 1983: 11).

This MRL non-compliance can be detected in the Exploitation Conversation 3 (EC3). The exploitation of MRL can be seen when Ungku Aziz answered Ungku Mukri's question in the statement (EC3/b) "my body is too tired". Thomas (1995) explained that MRL exploitation occurs through two situations, namely the situation (1) the speaker changes the topic of conversation or the situation (2) the speaker fails to provide relevant feedback to the question given to the speaker. The information or feedback given by the speaker in the statement (EC3/b) "my body is too tired" is completely irrelevant to the topic of discussion (the speaker's desire to follow Ungku Mukri to Singapore) which is just to apologize and state the condition of his tired body then, this statement coincides with the opinion of Thomas (1995) for the situation (2).

This conversation between Ungku Mukri and Ungku Aziz happened when Ungku Aziz wanted to go to Singapore because there was business. Ungku Mukri Question (EC3/a) "I am going to Singapore. Do you want to follow, Ungku Aziz?" has been reciprocated by Ungku Aziz by making unrelated contributions. To understand this unrelated contribution, the listener can use the literal meaning of Ungku Aziz's utterance as the beginner context. The listener should first take note on the literal meaning of the utterance used to obtain additional information or reference to the speaker's answer coincides with the opinion of Cutting (2002) that is when the speaker gives irrelevant feedback to the topic of discussion, the speaker actually expects the listener to get the true meaning of the utterance between the topic of discussion and the utterance of the speaker.

In the speaker's statement (EC3/b) "my body is too tired" there is a word that can be the main reference that is the word "tired". The listener has an encyclopedic entry and knows the meaning of the word "tired". "Tired" literally refers to not being energetic or tired. Based on Relevance Theory, the role of cognitive factors will help the listener relate the word "tired" to the context of the conversation to produce some premise in turn producing conclusions of the meaning of the actual utterance (Sperber \& Wilson, 1986). According to Carston (2004), a premise is a set of assumptions based on the context used in the utterance. Based on the context of the listener's knowledge of what is said to be "tired" then, some premise of the implicature of MRL exploitation implication (EC3/b) "my body is too tired" can be produced like:
Premises
1) Speaker is tired
2) Speaker does not have energy
3) If do not have energy, it is certainly best not to do any work of activity.
4) Speaker is tired are a strong reason for speakers not wanting to follow Ungku Mukri to Singapore

Based on the context provided by the speakers and listeners can also apply the existing knowledge context, the conclusion of the meaning of the utterance (EC3/b) is "Ungku Aziz does not want to follow the speaker to Singapore". The effect of this context is relevant because it can be linked to the topic of conversation, which is Ungku Aziz's desire to follow Ungku Mukri to Singapore in a statement (EC3/a) "I am going to Singapore. Do you want to 
follow, Ungku Aziz?". The contextual effect (EC3/b) "Ungku Aziz does not want to follow the speaker to Singapore" is also relevant because it can be linked to the context of the statement that was present before that "I am sorry". The previous statement used the word "sorry" which clearly means asking for freedom from any wrongdoing. The meaning of the previous statement "I am sorry" has a negative meaning that is to make a mistake. In the case of this Exploitation Conversation 3, the offense refers to the act of rejecting the speaker's question.

Based on the conclusions produced, the statement (EC3/a) "My body is tired" can be explained as MRL exploitation because Ungku Aziz gives irrelevant feedback according to the topics discussed but gives relevant contributions at the implied level. This statement can also be explained as the exploitation of MRL because Ungku Aziz gives a contribution that is not intended to confuse the listener because the statement used by Ungku Aziz can be a reference to the listener to get the necessary contribution.

The statement (EC3/b) "My body is too tired" can also be explained as the exploitation of MRL because the resulting contribution despite having neglected the needs of MRL, it still managed to meet the characteristics of effective contribution. By meeting the characteristics of effective contribution, this statement (EC3/b) Ungku Aziz succeeded in connecting with CP. The following is a summary of the MRL exploitation discussion.

Table 7. Summary of Exploitation MRL

\begin{tabular}{|c|c|c|c|c|}
\hline Utterances & $\begin{array}{l}\text { Exploitation } \\
\text { Strategy }\end{array}$ & $\begin{array}{l}\text { Exploitation } \\
\text { Maxim }\end{array}$ & Implicature & $\begin{array}{l}\text { Purpose of } \\
\text { Exploitation }\end{array}$ \\
\hline $\begin{array}{l}\text { I am sorry, my } \\
\text { body is too tired }\end{array}$ & $\begin{array}{l}\text { Provide } \\
\text { feedback that is } \\
\text { not related to } \\
\text { the topic }\end{array}$ & $\begin{array}{l}\text { MRL- does not } \\
\text { provide relevant } \\
\text { feedback by the } \\
\text { listener }\end{array}$ & $\begin{array}{l}\text { Ungku Aziz did } \\
\text { not want to } \\
\text { follow Ungku } \\
\text { Karim } \\
\text { Singapore }\end{array}$ & $\begin{array}{l}\text { The speaker } \\
\text { wants to reject } \\
\text { the listener's } \\
\text { invitation }\end{array}$ \\
\hline
\end{tabular}

\section{Exploitation Conversation 4}

\section{Table 8. Exploitation Conversation 4}

\begin{tabular}{|c|c|c|}
\hline (a) & Zaleha & $\begin{array}{l}\text { Ambik lah wang ini buat minum-minum kopi } \\
\text { Take this for your pocket money }\end{array}$ \\
\hline \multirow[t]{2}{*}{ (b) } & Ghazali & $\begin{array}{l}\text { Tak payah cik, tak payah. Pertolongan kami bukan } \\
\text { mengharapkan wang }\end{array}$ \\
\hline & & It is alright miss, no need. We help not because we want \\
\hline \multirow[t]{3}{*}{ (c) } & Sudin & Duit tu bodoh \\
\hline & & That is money stupid \\
\hline & & EC4/00.20.16 \\
\hline
\end{tabular}

MMN is a maxim that emphasizes the value of clarity of a given contribution. This MMN suggests that the contribution of communication should be clear that is not using expressions that can cause confusion. The statement used is not ambiguous, inaccurate, should be clear and orderly. This MMN non-compliance will occur when the speaker gives a vague statement (Grice, 1975).

This MMN exploitation can be seen present in the Exploitation Conversation (EC4). Speech (EC4/c) is detected as a speech that exploits MMN. This statement (EC4/c) was uttered by Sudin when Sudin heard Ghazali reject the money offered by Zaleha. This conversation 
took place when Sudin and Ghazali helped Zaleha push her car which could not move because the tire was stuck. This statement (EC4/c) is Sudin's response to Ghazali's statement.

Ghazali's statement that rejected Zaleha's money can be seen in the statement (EC4/b) "It is alright, no need. We help not because we want money". Ghazali's statement was later answered by Sudin with (EC4/C) "That is money stupid". Sudin's statement is seen as not fulfilling the recommendation of effective contribution according to MMN where Sudin gives a vague contribution.

(EC4/c) "That is money stupid" does not meet the requirements of MMN because the utterances used can give rise to various assumptions, but only assumptions that are relevant to the listener will be processed by the listener. In the utterance (EC4/C) "That is money stupid" there are two assumptions of utterance namely 1) the money is stupid or 2) it is money, stupid. The two differences of this assumption are "stupid" is the nature of money or even stupid refers to the nature of Ghazali.

To get a truly relevant assumption, listeners can take advantage of encyclopedic notes through the meaning of "money" and "stupid". This encyclopedic entry can be a starting point for dropping the assumptions formed. The listener knows that "money" is an item or object that is used as a medium in trading. While "stupid" refers to difficult to understand and do not know how to distinguish good or bad things. With reference to the act of Ghazali rejecting the money given, then the context of the originator gives the assumption "objects used as a medium of sale and purchase are difficult to understand and do not know how to differentiate something". The listener knows that the context of this assumption is not able to conclude the true meaning of Sudin. The listener will use the input given by Sudin in his speech and connect with the context of his knowledge.

Based on the context of the listener's knowledge, "money" is an important object in the business of buying and selling. Acceptance of an item or service offered can be obtained with money. So money is considered as something important in human life. Sudin and Ghazali have come to know clearly that the thing Zaleha wants to give is money. This can also be seen through the statement of Zaleha who wants to give Sudin and Ghazali money as a reward to help him as in the statement (EC4/a) "Take this for your pocket money".

Apart from that, the listener can also take advantage of the words that were present before that, namely (EC4/b) "It is alright, no need. We help not because we want money". The previous statement shows that Ghazali rejected the money given by Zaleha, so the previous statement could be additional information to the listener. To conclude the meaning (EC4/c) "That money is stupid" then Sudin's statement uses assumption 2) "That is money, stupid", the premise that can be produced are:

Premises 1) Sudin told Ghazali that what Zaleha offered was money

2) That money is something that is so valuable

3) Refusing to accept money is a foolish act

4) Sudin said Ghazali was stupid for rejecting money

Based on the context, the listener can conclude the meaning (EC4/c) as "Sudin wants Ghazali to take the money given by Zaleha". The effect of this context is relevant to the context of the knowledge of the value of valuable money and the context of the speaker's belief in the act of rejecting money is a foolish act. The input of "money" and the context present in this statement are successfully linked to form a relevant conclusion. This coincides 
with the argument of Wilson and Sperber (2006) that input and context are two aspects that are needed together and interdependent to achieve the context effect.

Based on the conclusion "Sudin wants Ghazali to take the money given by Zaleha", the statement $(\mathrm{EC} 4 / \mathrm{c})$ " That is money stupid " can be explained as MMN exploitation because the speaker has given clear information at the implied level. Speech (EC4/c) is also seen as deliberately done by the speaker by giving an obscure contribution because the speaker wants the listener to know that the speaker is not complying with MMN. Ghazali realized that Sudin did not want to tell that the thing was money but expressed Sudin's desire for him to take the money.

The speaker deliberately uses the word "stupid" to help the listener get his speech contribution. Sudin is seen as deliberately not meeting the needs of MMN. Sudin was able to fully express his desire for Ghazali to take the money offered by Zaleha. But Sudin chose not to fulfill MMN on purpose because he wanted Ghazali to get the real meaning behind his words. Sudin's wishes were not clearly stated based on the context of the relationship, where Sudin and Ghazali did not know Zaleha and in order to avoid awkwardness, Sudin asked Ghazali to take the money by using the expression that exploited MMN.

In addition (EC4/c) can also be explained as a statement that exploits MMN because the resulting contribution can be linked to $\mathrm{CP}$ that is, the resulting contribution provides benefits to speakers and listeners. Sudin benefits by the way Ghazali knows the utterance he gives contains the necessary contributions while the benefit for Ghazali is that ghazali can clearly understand the contribution given by Sudin. The following is a summary of MMN exploitation discussions.

Table 9. Summary of Exploitation MMN

\begin{tabular}{|l|l|l|l|l|}
\hline Utterance & $\begin{array}{l}\text { Exploitation } \\
\text { Strategy }\end{array}$ & $\begin{array}{l}\text { Exploitation } \\
\text { Makxim }\end{array}$ & Implicature & $\begin{array}{l}\text { Purpose of } \\
\text { Exploitation }\end{array}$ \\
\hline $\begin{array}{l}\text { That is money } \\
\text { stupid }\end{array}$ & $\begin{array}{l}\text { Make a vague } \\
\text { contribution. }\end{array}$ & $\begin{array}{l}\text { MMN-do not } \\
\text { make vague } \\
\text { contributions }\end{array}$ & $\begin{array}{l}\text { Sudin wants } \\
\text { Ghazali to take } \\
\text { the money }\end{array}$ & $\begin{array}{l}\text { Ask the listener } \\
\text { to make } \\
\text { something. }\end{array}$ \\
\hline
\end{tabular}

\section{Research Implications}

The exploitation of CPM succeeded in showcasing the values and thoughts of a society based on the contribution of utterances made creatively manipulating the general guidelines of conversation. Although every human being has been equipped with the desire to contribute to the conversation and always expect the contribution he receives to comply with his wishes, yet human beings still do not do that when involved in communication. Exploitation in the Malay community conversation proves the greatness of the mindset of Malay community in violation of the general rules of the conversation but still manages to convey what he meant. Exploitation detected also demonstrates the reality of the community speaking the creative does not comply with the guidelines in the conversation but also at the same time complying with effective presentation.

The behavior of the community that chooses to use utterances that exploit CPM when involved in various conversational situations is also seen to have its own value. The words that exploit CPM will occur in various conversational situations regardless of aspects of gender, age, distance of relationship or social status. Each module will be exploited intelligently by Malay society as a concept presented for this exploitation can be adapted and 
modified according to the speaker's intention thereby smoothing communication contributions to our listeners.

Exploitation has successfully proven its suitability and breadth of use when present in conversations regardless of relationship or gender as in utterances that occur in family communication as in PE1, intimate relationships in EC2, conversations between friends as in EC3 and PE4. Exploitation detected in this conversation situation successfully demonstrates the wisdom of the community wanting to manipulate the audience by giving the listeners what they want but do not provide a way through what the listeners want. Exploitation of this module also highlights the beauty of the language, intelligence, sharpness of thought and traditions of the community when engaged in a conversation stage.

This exposure to exploitation can also be successfully revealed by using film as a conversation model. The film has previously received various views related to the authenticity of the language used. Through this exploitation, it is clear that the value of language authenticity in the film has been successfully demonstrated. CPM exploitation in the conversation through the film also successfully reflect the reality of the use of the Malay language. Clearly, the film manages to portray the reality of community life in terms of thinking, cultural intellect and even the use of language.

\section{Conclusions}

Exploitation detected successfully demonstrated the height of the thinking, aesthetic language, culture and philosophy of the Malay community when presenting the conversation. Exploitation is also present widely in the community conversation whether in conversations with individuals familiar or not familiar. This exploitation also succeeds in helping the speaker in various conversational situations with the same goal of making speech understandable to the listener as an effective contribution and making contribution meets the needs of the conversation. This contribution can be proven effective through the reference and context involved. So Grice Conversation Theory and Relevance Theory are seen to be able to explain the understanding of the meaning of utterances that exploit CPM. Even the interpretation of speech exploitation in the film is also seen as holding the reality of life in terms of culture and language of the Malay community. Every conversation featured in the film is also a manifestation of the reality of society today or even in the past.

\section{Corresponding Author}

Norhidayu Hasan

Department of Malay Language Faculty of Modern Language and Communication Universiti Putra Malaysia, Malaysia

Email: hidayuhasan92@gmail.com

\section{References}

Alvarez-Pereyre, M. (2008). Using Film As Linguistic Specimen: Theoretical And Practical Issues. In R. Piazza, M. Bednarek, \& F. Rossi (Eds.), Telecinematic Discourse: Approaches To The Language Of Films And Television Series (Pp. 47-69). Amsterdam: John Benjamins Publishing Company.

Andresen, N. (2014). Flouting The Maxims In Comedy : An Analysis Of Flouting In The Comedy Series Community (Dissertation). Retrieved From Http://Urn.Kb.Se/Resolve?Urn=Urn:Nbn:Se:Kau:Diva-31687 
Andriyani, A. A. D. (2015). Penerapan PK Dalam Tuturan Staf Gro Jepang Di Travel His Tour. Seminar Nasional Prasasti li (P. 256-265).

Bednarek, M. (2018). Language And Television Series: A Linguistic Approach To Tv Dialogue. New York: Cambridge University Press.

Bruti, S. (2016). Teaching Compliments And Insults In The Efl Classroom Through Film Clips. In Pragmatic Issues In Specialized Communicative Contexts (Pp. 149-170). Brill Rodopi.

Bruti, S. (2016): "Teaching Compliments And Insults In The Efl Classroom Through Film Clips." Francesca Bianchi, Sara Gesuato (Eds): Pragmatic Issues In Specialized Communication. Leiden: Brill, 149-170.

Carston, R. (2004). Relevance Theory, Grice And The Neo-Griceans: A Response To Laurence Horn's 'Current Issues In Neo-Gricean Pragmatics' . Intercultural Pragmatics, 2(3), 303319.

Ceballos, C. T., \& Sosas, R. V. (2018). On Court Proceedings: A Forensic Linguistic Analysis On Maxim Violation. Journal of Nusantara Studies, 3(2), 17-31. Doi: Http://Dx.Doi.Org/10.24200/Jonus.Vol3iss2pp17-31

David, K. M. (2016). Using movies to teach the speech act of refusals. Retrieved from https://www.researchgate.net/publication/305309139_Using_Movies_teach_ the_Speech_Act_of_Refusals

Davies, B. (2000). Grice's Cooperative Principle: Getting The Meaning Across. Leeds Working Papers In Linguistics And Phonetics, 8, 1-26.

Fiorelli, L. (2016). What Movies Show: Realism, Perception and Truth in Film. Publicly AccessibleMPenn Dissertations. 1715.

http://repository.upenn.edu/edissertations/1715

Giampieri, P. (2018). Spoken Language Features (And Anomalies) In Films For Esl Classes . Language Learning In Higher Education, 8(2), 399-425.

Grice, H. P. (1975). Logic And Conversation. In P. Cole And J. Morgan (Eds) Studies In Syntax And Semantics lii: Speech Acts, New York: Academic Press, Pp. 183-98.

Grice, H. P. (1989). Studies In The Way Of Words. Harvard University Press.

Hasan, N., \& Hamzah, Z. A. Z. (2018). Implikatur Dalam Filem 1957: Hati Malaya. Jurnal Bahasa. 35. 135-148.

$\mathrm{Hu}$, S. (2012). An Analysis Of Humor In The Big Bang Theory From Pragmatic Perspectives. Theory And Practice In Language Studies, 2(6), 1185-1190.

Jia, L. (2008). The Violation Of Cooperative Principle And The Four Maxims In Psychological Consulting. Canadian Social Science, 4(3), 87-95.

Kazemi, F., \& Ebrahimi, A. (2016). The Sudy Of Grice Principle Application In Commercial Advertisements Of Hamshahri And Jame Jam Newspapers. International Journal On Studies In English Language And Literature, 4(9), 1-10. Retrieved On 27th Of April 2018 From Www.Arcjournals.Org.

Levinson, S. C. (1983). Pragmatics. Cambridge: Cambridge University Press.

Liu, L. (2017). Application Of Cooperative Principle And Politeness Principle In Class QuestionAnswer Process. Theory And Practice In Language Studies, 7(7), 563-569.

Locher, M. A., \& Jucker, A. H. (2017). Pragmatics Of Fiction. Berlin: Walter De Gruyter Gmbh $\& \mathrm{Co} \mathrm{Kg}$.

Mcquail, D. (1994). Mass Communication Theory: An Introduction. University Of Michigan: Sage Publications.

Atan, M. (2010). Implikatur Dalam Ujaran Watak Dalam Filem Seniman Agung Tan Sri P.Ramlee. Phd Thesis : Universiti Putra Malaysia, Serdang. 
Mukaro, L., Mugari, V., \& Dhumukwa, A. (2013). Violation Of Conversational Maxims In Shona. Journal Of Comparative Literature And Culture, 2(4), 161-168.

Majeed, S. H., \& Abdulla, L. A. R. (2018). Non-Observance Of Conversational Maxims In The Exchanges Of Department Press Briefings. losr Journal Of Humanities And Social Science (losr-Jhss), 23(6), 67-86. Retrieved On 27th Of April 2018 From Http://Www.losrjournals.Org/losr-Jhss/Papers/Vol.\%2023\%20issue6/Version5/12306056786.Pdf

Moore, R. (2018). Gricean Communication, Joint Action, And The Evolution Of Cooperation. Topoi, 37(2), 329-341.

Ngenget, S. (2017). A Revisit Of The Gricean Maxims In Manado Malay Language. Script Journal: Journal Of Linguistic And English Teaching, 2(2), 204-211.

O'meara, J. (2018). Engaging Dialogue: Cinematic Verbalism In American Independent Cinema. Edinburgh University Press.

Piazza, R. (2010). Pragmatic Deviance In Realist Horro Films: A Look At Films By Argento And Fincher. In R. Piazza, M. Bednarek, \& F. Rossi (Eds.), Telecinematic Discourse: Approaches To The Language of Films And Television Series (Pp. 85-104). Amsterdam: John Benjamins Publishing Company.

Raja, M. R. S., \& Hamzah, Z. A. Z. (2015). Penggunaan Implikatur Sebagai Medium Penjelasan Akidah. Jurnal Linguistik, 19(2), 1-9.

Saimon, A., \& Hamzah, Z. A. Z. (2019). Ujaran Saling Memahami Dalam Filem Nordin Ahmad. Issues In Language Studies, 8(1), 162-180.

Santas, C. (2001). Responding To Film: A Text Guide For Students Of Cinema Art. Chicago: Burnham Publisher

Simin, S., Bahadori, F., \& Bagherzade, N. (2016). Gendered-Based Use Of Maxim Of Quantity In Iranian Spoken Discourse: A Case Of Closing Conversation. The Philologist, (1), 1-7.

Sobhani, A., \& Saghebi, A. (2014). The Violation Of Cooperative Principles And Four Maxims In Iranian Psychological Consultation. Open Journal Of Modern Linguistics, (4), 91-99. Http://Dx.Doi.Org/10.4236/Ojml.2014.41009

Sukriawati. (2019). A Gricean Maxim Analysis In Efl Classroom Interaction (Dissertation). Retrieved From Http://Eprints.Unm.Ac.Id/Id/Eprint/15203.

Sperber, D., \& Wilson, D. (1986/1995). Relevance. Communication \& Cognition. Oxford UK \& Cambridge USA: Blackwell.

Thomas, J. (1995). Meaning In Interaction: An Introduction To Pragmatics. London: Longman.

Wilson, D. (2016). Relevance Theory. In Y. Huang (Ed.), Oxford Handbook of Pragmatics. Oxford University Press.

Wilson, D., \& Sperber, D. (2006) Relevance theory. In: Ward, Gregory L., Horn, Laurence R. (Eds.), Handbook of Pragmatics. Blackwell, Oxford.

Wilson, D. \& Sperber, D. (2002) Truthfulness and relevance. Mind, 111. 583-632.

Yuvike, Y., \& Winiharti, M. (2009). The Non-Observance Of The Conversational Maxims: An Analysis Of The Dialogues In Arthur Miller's The Crucible. Lingua Cultura, 3(2). Doi:10.21512/Lc.V3i2.338.

Zahid, I. (2018). Analisis Maksim Perbualan Grice Dalam Soal Jawab Tv3. Issues In Language Studies, 7(2), 16-35. Doi: Https://Doi.Org/10.33736/Ils.1225.2018 